\title{
CONVICTION APPEALS TO THE COURT OF APPEAL OF ALBERTA: A STATISTICAL ANALYSIS, $1985-1992$
}

\section{PETER McCORMICK}

Although the Provinciul Courts of Appeal perform the same role within the Canadian judicial system. they do not share a similarity in caseload. Alberta's Court of Appeal is unique in the sense that although Albersa is the fourth largest province, it handles more comviction appeals as an absolute number than any other province. Through an onalysis of various statistical surveys. McCormick explores this phenomenom. His work centres around conviction from 1985 to 1992 and it reveals trends that have developed during that time.
Bien que les Cours d'appel provinciales aient te même rôle au sein de l'appareil judiciaire canadien. leur volume de iravail n'est cependant pas semblable. Le cas de I'Alberta est unique à cet égard. Bien qu'il s'agisse de la quatrième province canadienne en importance. on y irouve un plus grand nombre de comdamnations portées en appel que partout ailleurs au pays. McCornick a precédé à l'analyse de ce phénomiene en s'appuyant sur l'analyse de plusieurs enquècs statistiques. Ses travaux reposemt sur tes années 1985-1992 et révèlent les tendances à lineunre durain cettc éperque.

TABLE OF CONTENTS

I. INTRODUCTION .................... 301

II. THE ALBERTA COURT OF APPEAL IN A

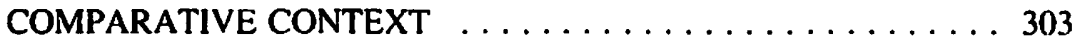

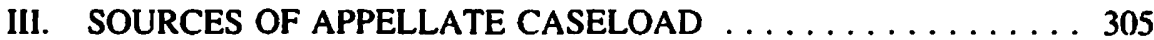

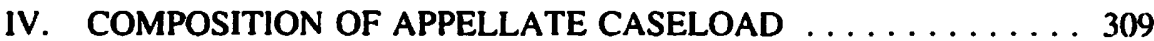

V. CORRELATES OF APPELLATE REVERSAL $\ldots \ldots \ldots \ldots \ldots 311$

VI. THE USE OF $A D$ HOC JUDGES $\ldots \ldots \ldots \ldots \ldots \ldots \ldots \ldots 313$

VII. CASEFLOW IN THE ALBERTA

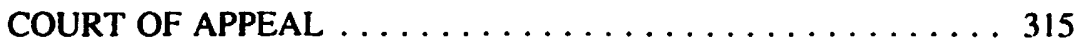

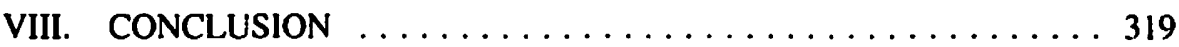

\section{INTRODUCTION}

The Alberta Court of Appeal occupies the same important but somewhat anomalous position as the other provincial courts of appeal it sits at the apex of the provincial court system, but is itself subject to the supervisory appellate overview of the Supreme Court of Canada.' However, with the restricted caseload of the Supreme Court of Canada

I wish to acknowledge the support of the Alberta Law Foundation. which funded the data collection for this project. and the three student research assistants who helped me in collecting and coding the data: Alex Kotkas, now at the University of Alberta: Scott McCormick, now at the University of Western Ontario; and Tim Moro. at the University of Calgary.

1. Not surprisingly, the review of prior decisions of the provincial courts of appeal continues to provide the hulk of the Supreme Court caseload in recent years, some $8.5 \%$ of the total, with the bulk being made up of appeals from the Federal Court, rehearings of various sorts, and per saltum appeals from provincial superior trial courts. See McCormick. "The Supervisury Role of the Supreme Court of Canada": Supreme Courl Law Review, forhcoming. 
and its increasing focus in recent years on public law cases, ${ }^{2}$ the provincial appeal courts are playing an increasingly pivotal role, and their behaviour and performance merits closer attention.

The purpose of this paper is to provide a statistical analysis of conviction appeals to the Alberta Court of Appeal from January 1, 1985 to June 30, 1992. These dates are more opportunistic than logical quite simply, the Registrar's Office in Edmonton does not retain as archival material the summary lists on which this study is based. However, they coincide very closely with the Chief Justiceship of Mr. Justice J.H. Laycraft; Justice Laycraft was appointed Chief Justice of the province on February 20, 1985 and Justice Fraser was appointed to succeed him on March 12. 1992. This conveniently sets the tone for the examination to follow: neither critical nor rigorously comparative, but simply a close statistical snapshol of the recent performance of one of the more active ${ }^{3}$ and respected $^{+}$of the provincial courts of appeal.

The analysis of appeal court decisions is morc often carried out in terms of the discursive ${ }^{5}$ analysis of legal doctrine as it emerges and is claborated in specific decisions; decisions consist of words and ideas, which at one and the same time determine the "winner" of the specific casc and contribute to a body of law that will guide the process of determining "winners" in future cases. There is an unavoidable degree of simplification in reducing this to flat statistical categories both the one-paragraph dismissal of a defendant's wishful thinking and a careful and reasoned rejection of a Crown argument on the Charter implications for breathalyser cases, are coded as "appeal dismissed." This abstraction (even trivialization) of intellectual content means that findings based on general statistical patterns must be treated with some caution. To defend the statistical approach, the suggestion is not that the reduction should or could replace discursive analysis, but simply that it provides information about the context of specific decisions in the form of long-term patterns. By the very nature of things, some cases must be more unusual than others, some outcomes more predictable and ordinary. The purpose of this study is to provide some of the background against which these assessments can be made; to describe the forest as a means of bettcr understanding the provenance of a specific tree.

: See. for example. P. Monahan. Politics and the Comstitulien: The Charter. Federalism and the Sipreme Court of Canada (Toronto and New York: Carswell/Methuen, 1987), c. 2 "Changing the Court's Business: The Evolution of the Court's Dockel. 196()-85".

$\therefore \quad$ The Alberta Court of Appeal has the third, and in recent years possibly the second. highest caseloud of all the Canadian courts of appeal. Sce P. McCormick "Canadian Provincial Courts of Appeal: A Comparison of Procedures" (Paper presented at 1992 Canadian Appellate Court Seminar, May 1992) |unpublished|.

$+\quad$ On subsequent uppeal to the Supreme Court of Canada, the Alberta Court of Appcal is reversed less often than most other provincial appeal courts. See P. McCormick, "Alberta"s Court of Next to Last Resor: Appeals from the Alberta Court of Appcal to the Supreme Court of Canada, 1970-1991)" (1991) 29 Alta L. Rev. 861.

In the sense of its core meaning: "passing from premises to conclusions; ratiocinative las opposed to intuitive|" rather than its more figurative nieaning of "rambling. digressive." Shorter Oxford English Dictionury: 
The data on which the analysis is based were generated from the monthly case-lists maintained by the Office of the Registrar of the Court of Appeal in Edmonton and Calgary; ${ }^{6}$ focusing on three or five-judge panel decisions and, therefore, excluding chambers proceedings. These records are not maintained in identical format in both centres even today, and there have been changes to both the format and the completeness of the records over time. The data base is, therefore, less than perfect, and the total number of cases from which statistics have been generated may differ slightly from one part of the paper to another.

\section{THE ALBERTA COURT OF APPEAL IN A COMPARATIVE CONTEXT}

The Alberta Court of Appeal is one of ten provincial superior appeal courts, ${ }^{7}$ nine of which operate within the British common law tradition and all of which oversee the application of a uniform national criminal code. One would expect from this a certain similarity in the caseload of the various appeal courts, modified perhaps to accommodate differing provincial population size and possibly different sizes of the provincial courts of appeal. This expectation is in fact far wide of the mark, as indicated by Table 1.

The comparative numbers in Table $I$ lack any clear pattern neither regional nor population considerations seem consistently to explain the variations. There is some logic to the numbers for civil appeals: if we set aside Quebec as a special case because of its civil code system, then a province always has more civil appeals than any smaller province. However, the attempt to translate this into a consistent ratio (civil appeals per hundred thousand of population) fails. The numbers for criminal appeals lack even this initial logic; there is no clear pattern for the number of criminal appeals, the ratio of criminal to civil appeals, and the ratio of criminal appeals to population. For example, Alberta has significantly fewer civil appeals than B.C., but three times as many criminal appeals. ${ }^{8}$ Among the provincial courts of appeal, Alberta has the highest ratio of criminal to civil appeals, followed by Newfoundland and Ontario. Quebec has the lowest, a practical face to the formal difference implied by that province's civil code regime.

a I wish (o) indicatc my appreciation for the friendly conperation of the Office of the Registrar of the Court of Appeal in hoth Fumonton and Calgary who gave me access to the records and facilities to record the results and to Chicf Justice Laycraft and Chief Justice Fraser, whose permission and approval made the access possible.

However. it is only in recent decades that this has been the casc. Newfoundland only acquired its separatc appellatc court in 1974 and Prince Edward Island in 1987. See P.H. Russell, The Judiciary: in Canuda: The Third Branch of Government (Toronto: McGraw-Hill/Ryerson, 1987) c. 12.

To some extent, this is a difference in procedure and in the way that cases are counted: for example, the B.C.C.A. docs, and the Alberta C.A. does not. use "leave to appeal" as a screening mechanism. a formal separate stage that keeps some matter from full panel consideration. The point is not that the Alberta Cour of Appeal is padding its numbers; rather, it has chosen as a matter of policy 10 Icave the dour open to a larger number of appeals and to accommodate the greater caseload this creales. 
Table J: Criminal and Civil Annual Appellate Caseload Canadian Provincial Courts of Appeal"

\begin{tabular}{||l|c|c|c||}
\hline Province & $\begin{array}{c}\text { Civil } \\
\text { Appeals }\end{array}$ & $\begin{array}{c}\text { Criminal } \\
\text { Appeals }\end{array}$ & $\begin{array}{c}\text { Percentage } \\
\text { Criminal }\end{array}$ \\
\hline Alberta & 275 & 746 & $73.1 \%$ \\
\hline Newfoundland & 35 & 65 & $65.0 \%$ \\
\hline Ontario'0 & 492 & 837 & $63.0 \%$ \\
\hline Saskatchewan & 194 & 304 & $61.0 \%$ \\
\hline Manitoba & 184 & 243 & $56.9 \%$ \\
\hline Nova Scotia & 165 & 195 & $54.2 \%$ \\
\hline P.E.I. & 34 & 31 & $47.7 \%$ \\
\hline British Columbia & 405 & 286 & $41.3 \%$ \\
\hline New Brunswick & 106 & 58 & $35.4 \%$ \\
\hline Quebec & 830 & 321 & $27.9 \%$ \\
\hline TOTAL: & 2720 & 3086 & $53.2 \%$ \\
\hline
\end{tabular}

It is of course important to distinguish between conviction appeals and sentence appeals; the latter, usually less complex and demanding, can make up a significant proportion of the criminal caseload and misleadingly swell their numbers relative to civil caseload. It is a mistake to assume that the conviction/sentence/civil ratio in caseload in any sense parallels the normal weekly judicial workload. Sentence appeals are typically so straightforward that they can be "batch-processed" in large numbers; conviction appeals vary but are generally more routine and repetitive than civil appeals;" while the "civil" rubric is itself a residual category including an enormous diversity of cases, many of which call for significantly more reading and preparation. Moreover, the ratio of sentence appeals to conviction appeals within the criminal appeal category is itself far from

4. All data for calendar 1989; from McCormick "Provincial Appeal Procedures" op.cit., reviscd to include figures from British Columbia Court of Appeal Annual Report 1990.

III. Omits inmate appeals, a category which in practice includes a considerable overlap with the criminal appeals category.

11. See J.T. Wold, "Going Through the Motions: Monotony of Appellate Court Decisionmaking" (197879) 62 Judicature 58; and J.T. Wold \& G.A. Caldeiru, "Perceptions of 'Routine' Decisionmaking in Five California Courts of Appeal" (1980) 13 Polity 334. 
constant. For example, in Ontario the ratio is almost five to one ${ }^{12}$ while in Manitoba, in recent years, the numbers have been almost even. ${ }^{13}$

Alberta falls between these two extremes. Over the seven year period, conviction appeals have been almost exactly half as frequent as sentence appeals, and criminal conviction appeals make up almost one-quarter of the Alberta appellate caseload. This suggests rather a surprising conclusion: although Alberta is the fourth largest province, its court of appeal may well handle more conviction appeals as an absolute number, let alone as a percentage of total caseload than any other province, and this "fourth to first" jump suggests the dangers of generalizing findings about appeal court procedures.

Hard numbers of this sort are not available for a series of years for all the provincial courts of appeal. The Alberta figures suggest a gradual decline from a high just over 1350 cases in 1985-86 to stabilize around 1000 cases per year over the last three years. Fragmentary and anecdotal information from the other courts of appeal suggest that some (but not all) have experienced similar or greater declines in recent years, implying that the "remarkable growth in the volume of appeals" described by P.H. Russell in 1987 as "a general North American phenomenon over the last twenty-five years"14 has come to an end.

\section{SOURCES OF APPELLATE CASELOAD}

By definition, the caseload of the Alberta Court of Appeal consists of appeals reviews of judicial decisions arising from trials in the lower courts, primarily the Court of Queen's Bench (since 1979 the only provincial superior trial court in the province) but also from the Provincial Court where an indictable offence has been tried there upon election by the defendant. ${ }^{15}$ As well, some of the cases appealed from the Court of Queen's Bench are themselves summary conviction appeals from the Provincial Court. ${ }^{16}$ Table 2 provides the seven-year breakdown of the appellate caseload in these terms, with the success rate of appeals from each.

Based on Figures and comments in C. Baar, I. Greene. M. Thomas and P. McCormick, "The Ontario Coun of Appeal and Expeditious Justice" (1992) 30 Osgoude Hall Law Journal 261.

1.. "Cascload and Output of the Manitnba Court of Appeal 1991" Mamirobal Lew Journal (forthcoming)

11. P.H. Russell, The Judiciary in Canadt: the Third Branch of Government (Toronto: McGraw-Hill Ryerson, 1987) al 294. 
Table 2: Sources and Success Rates of Appeals to the Alberta Court of Appeal, 1985-1992

\begin{tabular}{||l|c|c|c||}
\hline \hline Source of Appeal & Number & $\begin{array}{c}\text { Percentage } \\
\text { of Total }\end{array}$ & $\begin{array}{c}\text { Success } \\
\text { Rate }\end{array}$ \\
\hline \hline Provincial Court & 577 & $28.9 \%$ & $41.4 \%$ \\
\hline Queen's Bench $^{17}$ & & & \\
second appeal & 285 & $14.3 \%$ & $31.2 \%$ \\
judge \& jury & 8 & $8.4 \%$ & $37.5 \%$ \\
judge alone & 1128 & $56.5 \%$ & $32.8 \%$ \\
Total Queen's Bench & 1421 & $71.3 \%$ & $32.5 \%$ \\
\hline TOTAL: & 1998 & & $35.2 \%$ \\
\hline
\end{tabular}

The figures in Table 2 suggest several general observations: The first is that the number of appeals is small relative to the total criminal caseload of trial courts. Although the news reports from any particularly high profile trial seem to suggest that appeal is almost automatic, so much so that the failure to appeal seems tantamount to an admission of guilt, this is in fact completely misleading. Appeals are statistically extremely rare and the appellatc caseload is a small fraction of the trial caseload. This simply underlines the fact that appeal is an exceptional, not a routine, dimension of the court system. As Justice Kerans has written, "it is no part of our tradition that the just resolution of a dispute necessarily includes a review of the trial decision. ${ }^{\text {"I }}$ This being so, appeal is not automatic, not simply a second chance for the losers at trial but, rather, a recourse to be available only when there is some real apprehension that the outcome may not have been appropriate (which is not necessarily the same as suggesting that the judge may have made a mistake). ${ }^{19}$ Most trial decisions are not subjected to appellate review.

The second observation is the fact that most appeals do not succeed: the "normal" outcome of an appeal is the upholding of the trial judge's decision, and this is twice as likely as a successful appeal. At a personal interview several years ago, an appeal judge suggested a "rule of three" governing the appellate caseload: one third of all cases should never have been appealed and were a waste of time; one third were dismissed; and one third were allowed. This rule of thumb is consistent with the reversal rate of conviction

17. That is: second appeal of summary conviction case from Provincial Court already appealed (1) Queen's Bench.

Ix. Justice Kerans, "A Review of Standands of Review" (Paper presented at 1992 Canadian Appellate Court Seminar, May 1992) (unpublished].

19. By way of contrast, in the continental judicial tradition, review is much more automatic and muline: see M.R. Damaska. The Faces of Justice and State Authority (New Haven and London: Yale University Press, 1986) at 47-56, who comments on the "relatively weak character of judicial review" in the Anglo-American systems. 
appeals in Alberta, and indeed with the behaviour of appeal courts more generally." Over the seven and a half years, reversal rates have been declining slowly but steadily from just over $35 \%$ in the 1980 s to just under $35 \%$ in the 1990 s.

These comments can be made even more strongly by including those appeals that were started but not pursued to a final judicial determination on the merits. Over the seven and a half years, the Edmonton Registrar's Office recorded a total of 1165 appeals that were either allowed or dismissed by a panel decision. Over the same period, 146 appeals were "abandoned," 21 were "abandoned in court," 37 were "deemed abandoned" and 43 were "dismissed for want of prosecution." ${ }^{21}$ Of the 1412 conviction appeals that were initiated in Edmonton, $17.5 \%$ (or just over one in six) were not pursued to completion. It seems reasonable to assume that these are comprised disproportionately of cases whose chances of success were small, and had they been pursued to conclusion, the reversal rate might well be even lower than the $35.1 \%$ indicated above. Less than $30 \%$ of all initiated conviction appeals are pursued to a successful conclusion.

The third observation is that there is a relatively high proportion of appeals direct from the Provincial Court, amounting to almost three-tenths of the total caseload. To the layperson, this at first glance is surprising; in a strict and formal hierarchy, one cannot by definition move from the "low" court to the "high" court without going through the "middle" court. This just demonstrates, however, that the Canadian court system is something less than a strict and formal hierarchy, ${ }^{22}$ and highlights both the importance and the frequency of the defendant's right to elect the mode and forum for trial for many indictable offenses. ${ }^{23}$ It also underlines Peter Russell's comments that Canadian provincial court judges "exercise a vast criminal jurisdiction which appears to be unmatched by the lower criminal courts of any other liberal democracy." ${ }^{24}$ From a slightly different angle, more than two fifths of the caseload of the Court of Appeal consists of cases that originated in Provincial Court, arising either in the form of a direct appeal from that Court, or as a second appeal on summary conviction from the Court of Queen's Bench. The normal expectation of major cases in provincial superior court, minor cases in provincial court, is clearly too simple to catch the reality. At the same time, it should be noted that there has been a modest but persisting decline in the proportion of

"Research shows that state supreme courts affirm more than $60 \%$ of the lower coun decisions that they review." C. Emmert, "An Integrated Case-Related Model of Judicial Decision-making" (1992) 54 Journal of Politics. 548; see also B. Cartwright et al., "Courting Reversal: The Supervisory Role of State Supreme Courts" (1978) 87 Yale Law Journal 1191.

1. Although the consequences are much the same, I take it that the designations "abandoned" or "abandoned in cour" indicate explicit decisions by the appellant, "dismissed for want of prosecution" is clearly a judicial decision (albeit a pro forma one) made by a panel of judges, and "deemed abandoned" appears to be an administrative determination.

To make the point explicitly: on indictable offenses, the Provincial Court and the provincial superior trial court do nol comprise a judiciary hierarchy but are courts of coordinate and partially overlapping jurisdiction, both subject to review by the Court of Appcal. to the provincial superior courts by s. 427 of the Criminal Code. However, appeals involving. for example, assault are from provincial court as often as from Queen's Bench. 
provincial court appeals (from $32 \%$ in 1985 to $27 \%$ in 1990 and 1991) in the appellate caseload. I do not wish to make too much of this point: the Court of Appeal spends more time reviewing the decisions of Queen's Bench justices than it does looking at Provincial Court decisions, and given the caseload volumes of the two trial benches, it is unquestionably true that there are proportionately more appeals from Queen's Bench than from Provincial Court.

The fourth observation is the striking rarity of appeals from jury trials. The Alberta Court of Appeal is often called upon to second-guess or over-rule judges, but rarely to second-guess a jury's decision. ${ }^{25}$ Jury trials are not a major component of the Canadian judicial process (although they are more frequent than they were twenty years ago), so it is possible that the 140:1 ratio of judge alone to jury trials among the Queen's Bench appeals simply replicates the relative rarity of this phenomenon. Also, it is possible that there is less leverage for an appeal because of the fact that juries (unlike judges) do not have to give formal reasons for their decisions. It does not appear that appeals from jury trials are any more or any less likely to succeed.

The fifth observation is the significant and consistent (repeated for each year and for all types of offenses) difference in the success rates for appeals from Provincial Court and Court of Queen's Bench, with the success rate for an appeal from the provincial bench being almost $10 \%$ higher than that for appeals from provincial superior trial court. It is tempting, but possibly premature, to read this as a crude indicator of merit and, therefore. as confirming the notion of a hierarchy of ability that corresponds to the hierarchy of courts. At the same time, there are also grounds for suggesting that it is fairer to see this as a reflection of the different circumstances under which provincial judges work, with higher caseloads, shorter trial time, less opportunity for reading and research, and less time set aside for focused decision writing.

Table 3: Number of appeals and frequency of reversal, by bench Alberta Conviction Appeals, 1985 to 1992

\begin{tabular}{||l|cr|c|cc||}
\hline $\begin{array}{l}\text { Number of } \\
\text { Appeals }\end{array}$ & \multicolumn{2}{|c|}{ No. of Judges } & Reversal & \multicolumn{2}{|c|}{ No. of Judges } \\
& QB $\quad$ ProvCt & Frequency & QB & ProvCt \\
\hline \hline $40+$ & 1 & - & $60 \%+$ & 2 & 23 \\
\hline $30-39$ & 10 & - & $50-59 \%$ & 5 & 14 \\
\hline $20-29$ & 24 & - & $40-49 \%$ & 6 & 8 \\
\hline
\end{tabular}

3. It is also possible that the records in the Registrar"s Oflice do not reliably include the comment "und jury" after the judge's name. and that this is a matter of under-reporting rather than a low rate of appcals.

* Omits all judges with only one appeal. 


\begin{tabular}{||l|cc|c|cc||}
\hline $\begin{array}{l}\text { Number of } \\
\text { Appeals }\end{array}$ & \multicolumn{2}{|c|}{$\begin{array}{c}\text { No. of Judges } \\
\text { QB }\end{array}$} & $\begin{array}{c}\text { Reversal } \\
\text { FrovCt }\end{array}$ & \multicolumn{2}{|c|}{$\begin{array}{c}\text { No. of Judges } \\
\text { Frequency }\end{array}$} \\
\hline $10-19$ & 27 & 13 & $30-39 \%$ & 29 & 20 \\
\hline $5-9$ & 6 & 37 & $20-29 \%$ & 18 & 13 \\
\hline $1-4$ & 7 & 62 & $10-19 \%$ & 8 & 4 \\
\hline & & & $0-9 \%$ & 1 & 13 \\
\hline
\end{tabular}

The 1,998 appeals came from the trial decisions of 187 different judges, 75 on the Court of Queen's Bench and 112 on the Provincial Court. This means that there are very few judges in the province whose performance has not been subject to review by the Court of Appeal through the mechanism of a conviction appeal although there are some (about a dozen, mostly provincial judges) who have escaped such scrutiny. Other judges are appealed much more often; a single justice of the Queen's Bench was appealed 58 times, one provincial judge eighteen times. There are one dozen Queen's Bench judges who together account for $35 \%$ of the appeals from their bench, and one dozen provincial judges whose decisions make up $30 \%$ of the appeals from their bench, over the seven and a half year period. To be sure. part of this variation is caused by the length of the time span considered in that the retirement and appointment of judges means that some served for only part of the period; however, a considerable difference remains. The obvious conclusion, however, is clearly false: that is, it is demonstrably not the case that a specific subset of Alberta judges are appealed often because they are reversed often. The twelve most frequently appealed Queen's Bench judges, and the twelve Queen's Bench justices with the highest reversal rate, are twenty-one different individuals. Similarly the twelve most frequently appealed provincial judges, and the twelve provincial judges with the highest reversal rate, are twenty-three different individuals. Whatever drives the frequency of appeals from the decisions of a specific judge, it is something other than an objectively accurate perception of the frequency of error.

\section{COMPOSITION OF APPELLATE CASELOAD}

Given the diversity of the appellate caseload, a single overall success rate is not very useful. Table 4 refines this general information by dividing the caseload data among half a dozen major categories of offenses, indicating numeric totals and success rates for the major sub-categories where the grouping is obvious. Where a conviction appeal involved multiple offenses (they generally did not), the more serious category has been used, and there has been no attempt to account for or report multiple offenses.

It is hardly to be expected that this breakdown of caseload in any way mirrors that of the trial courts generally. On purely logical grounds, it is undoubtedly the case that the appellate caseload is skewed heavily toward the more serious and significant components of the trial caseload. For one thing, the normal outcome of a guilty determination in a criminal trial in Canada is a fine rather than imprisonment, while the appellate caseload 
is composed overwhelmingly of criminal convictions that drew a jail sentence. Similarly, the six-to-one preponderance of indictable offense appeals over summary conviction appeals reflects both the additional appellate stage and the lower stakes at issue.

Table 4: Elements of Caseload and Success Rates

Alberta Court of Appeal, 1985 to 1992

\begin{tabular}{|c|c|c|c|}
\hline Type of Offense & appeals & as \% of caseload & $\begin{array}{l}\text { success } \\
\text { rate }\end{array}$ \\
\hline $\begin{array}{l}\text { crimes against the person } \\
\text { assault } \\
\text { robbery } \\
\text { sex assault } \\
\text { murder } \\
\text { other } \\
\text { TOTAL: } \\
\end{array}$ & $\begin{array}{c}192 \\
166 \\
166 \\
123 \\
37 \\
684 \\
\end{array}$ & $\begin{array}{r}9.7 \% \\
8.3 \% \\
8.3 \% \\
6.2 \% \\
1.9 \% \\
34.4 \% \\
\end{array}$ & $\begin{array}{l}29.2 \% \\
30.1 \% \\
38.0 \% \\
26.8 \% \\
13.5 \% \\
30.2 \% \\
\end{array}$ \\
\hline $\begin{array}{l}\text { crimes against property } \\
\text { break \& enter } \\
\text { theft } \\
\text { stolen property } \\
\text { fraud/false pretences } \\
\text { other } \\
\text { TOTAL: }\end{array}$ & $\begin{array}{c}143 \\
137 \\
78 \\
75 \\
53 \\
486 \\
\end{array}$ & $\begin{array}{r}7.2 \% \\
6.9 \% \\
3.9 \% \\
3.8 \% \\
2.7 \% \\
24.4 \% \\
\end{array}$ & $\begin{array}{l}33.6 \% \\
51.8 \% \\
37.2 \% \\
32.0 \% \\
35.8 \% \\
39.1 \%\end{array}$ \\
\hline $\begin{array}{l}\text { motor vehicle offenses } \\
\text { driving over } .08 \\
\text { breath sample } \\
\text { impaired driving } \\
\text { dangerous operation } \\
\text { other } \\
\text { TOTAL: } \\
\end{array}$ & $\begin{array}{r}159 \\
77 \\
70 \\
43 \\
30 \\
379 \\
\end{array}$ & $\begin{array}{r}8.0 \% \\
3.9 \% \\
3.5 \% \\
2.2 \% \\
1.5 \% \\
19.1 \% \\
\end{array}$ & $\begin{array}{l}36.5 \% \\
23.4 \% \\
27.1 \% \\
44.2 \% \\
53.3 \% \\
34.3 \% \\
\end{array}$ \\
\hline $\begin{array}{l}\text { wrongful acts } \\
\text { weapons offenses } \\
\text { other } \\
\text { TOTAL: }\end{array}$ & $\begin{array}{c}52 \\
141 \\
193 \\
\end{array}$ & $\begin{array}{l}2.6 \% \\
7.1 \% \\
9.7 \% \\
\end{array}$ & $\begin{array}{l}21.1 \% \\
54.6 \% \\
45.6 \% \\
\end{array}$ \\
\hline drug-related offenses & 142 & $7.1 \%$ & $38.0 \%$ \\
\hline miscellaneous & 105 & $5.3 \%$ & $25.7 \%$ \\
\hline TOTAL: & 1989 & & $35.1 \%$ \\
\hline
\end{tabular}


Young offender appeals account for barely $3 \%$ of all appeals and are significantly more likely to succeed than adult appeals $(45.5 \%$ compared to $34.4 \%)$. Similarly, appeals involving femalc defendants are relatively unusual (less than one appeal in thirty) and are also more likely to succeed than appeals by male defendants (43.7\% against $34.4 \%$ ). Thesc two effects appear to be cumulative of the ten appeals by female young offenders, six wcre successful. These differences seem quite pronounced and consistent, but the numbers are so small as to make them of limited usefulness. The overwhelming majority of the cases in the conviction appellate caseload involve male adult offenders in their $20 \mathrm{~s}$ and $30 \mathrm{~s}$.

\section{CORRELATES OF APPELLATE REVERSAL}

The most dependable predictor of appellate success is simplc: which party is appealing the trial decision? Crown appeals are more likely to succeed than defense appeals by a striking margin of almost two to one $55.2 \%$ to $31.3 \%$. It would of course be both superficial and unfair to see this simply as a pro-Crown predilection on the part of appeal judges: a better explanation is both obvious and logically simple but nonetheless significant in its impact.

Marc Galanter has argued that there is a critical difference in the way that our judicial system generally (and therefore by logical extension appellate courts specifically) serve two general categories of litigant "one-shotters" (meaning those who make very few appcarances in court. largely involuntary) and "repeat performers" (meaning those actors for whom court decisions are a routine and regular component of official activities)."? Although these categories are of broader application, they clearly catch criminal defendants on the one hand and the crown prosecutor's office on the other. For defendants, the decision to appeal grows from a combination of advice by counsel, financial means. and the negative impact of the particular sentence: if the impact is sufficiently devastating, then even a remote chance of success logically justifies an appeal. By contrast, the Crown can both organize its appeals on the basis of a coherent and longterm strategy and decide on a broader and more rational basis where to locate the cut-off point of cost versus probable outcome. The advantages of bureaucratic organization also suggest that it can do so on the basis of more complete and systematized information as well. Further, the fact that Crown appeals are restricted to questions of law ${ }^{2 x}$ differentiates their appeals from the broader range of defendant appeals. some of which amount to littlc more than wishful thinking that the appeal court will retry the case.

This in turn suggests that the information in Table 4, rclating varying success rates to different components of the appellate caseload, could be fundamentally misleading. Given the massive differential between the success rates for Crown and for defendant appcals, the reversal rates for different types of offense are only strictly comparable if the ratio of defendant to Crown appeals remains fairly constant, and there is no logical or structural reason to think that it does. We can assume that defendant appeals are a product of trial 
sentencing practices, specific individual situations making the gamble of an appeal more attractive, and specific features of individual trials that raise some prospect of reversal on procedural grounds these are factors that should be reasonably constant over time. But Crown appeals are also the product of a bureaucratic decision anticipating a line of decisions that differs from that of the trial bench (and will therefore ripple out to influence the pattern of future trials), and of a willingness to invest the legal resources to bring about that change. In other words, the ratio itself is an important statement of the extent to which appeals within a particular area of law, and therefore the patterns of results that emerge, are "defendant pulled" or "Crown pushed."

Similarly, a certain level of success can be taken as the "normal" product of crror correction and judicial uniformity (that is: endorsing a specific trial judge's innovation from several plausible but mutually exclusive alternatives) and only a higher-than-normal reversal rate suggests deliberate appellate redirection of trial behaviour. Putting the matter in its crudest terms: given that many defendants plead guilty and that most trials end in determinations of guilt, it could be said that the major function of trial courts is to process criminal charges by registering the convictions of accused persons. From this same perspective, the general function of appeal courts is (through sheer weight of numbers) to turn the balance very slightly back in favour of the accused. That is, Crown appeals arc about twice as likely to succeed, while defendant appeals are seven times as numerous. This crude ratio of appeal frequency and success rates is, if you will, the norm or "carrier signal," and variations from it are the basis for the extraction of specific meaning. Table 5 presents the data on this basis.

Table 5: Frequency and Success Rate of Crown Appeals. by Type of Offense; Alberta Court of Appeal 1985-1992

\begin{tabular}{||l||c|c|c||}
\hline Type of Offense & $\begin{array}{c}\text { \% of appeals } \\
\text { by Crown }\end{array}$ & $\begin{array}{c}\text { Crown appeal } \\
\text { Success rate }\end{array}$ & $\begin{array}{c}\text { Defendant Appeal } \\
\text { Success Rate }\end{array}$ \\
\hline \hline motor vehicle & $23.2 \%$ & $62.5 \%$ & $25.8 \%$ \\
\hline drug-related offenses & $23.9 \%$ & $55.9 \%$ & $32.4 \%$ \\
\hline $\begin{array}{l}\text { crimes against the } \\
\text { person }\end{array}$ & $12.6 \%$ & $41.9 \%$ & $28.5 \%$ \\
\hline $\begin{array}{l}\text { crimes against } \\
\text { property }\end{array}$ & $9.3 \%$ & $44.4 \%$ & $38.6 \%$ \\
\hline \begin{tabular}{l} 
wrongful acts \\
\hline miscellaneous
\end{tabular} & $29.0 \%$ & $67.9 \%$ & $38.0 \%$ \\
\hline TOTAL: & $12.4 \%$ & $69.2 \%$ & $18.9 \%$ \\
\hline
\end{tabular}

In these terms, the pattern is rather different from that suggested in Table 4. It is not after all the case that appeals on drug-related offenses have a better than average chance 
of being reversed; instead, the success rates for both Crown and defendant appeals are almost exactly the overall average, and the apparent difference in reversal rate is driven by a higher than average proportion of Crown appeals ("Crown push") which does not seem to be meeting with any unusual degree of success. The net result is relative stability. Further, the appearance from Table 4 that motor vehicle offenses have a reversal rate below average is even more illusory; in fact, an unusually high ratio of Crown appeals is meeting with a considerable degree of success, while defendant appeals are less likely than average to succeed. ${ }^{24}$ On the other hand, appeals on crimes against property show the reverse category a very low proportion of Crown appeals which nonetheless succeed less often than average, while defendant appeals succeed more often than average.

\section{THE USE OF $A D$ HOC JUDGES}

Information is available on the panels for 1,998 of the conviction appeal decisions. 1362 (or about two-thirds) of these included only Appeal Court judges (including seven five-judge panels), 625 were composed of two appeal judges and one provincial superior trial judge sitting ad hoc, and 11 were composed of one appeal judge and two ad hoc judges. Over the total period, there were ad hoc judges on $31.8 \%$ of the conviction appeals, and appearances by ad hoc judges accounted for $10.8 \%$ of all panel assignments.

This is one of the distinctive features of the Alberta Court of Appeal. In British Columbia and Ontario, trial judges never sit as ad hoc members of the Court of Appeal. ${ }^{31}$ In Saskatchewan, Manitoba and the Atlantic provinces it occurs only in unusual circumstances, when for one reason or another" it is not possible to form a panel of appeal court judges. For example, in Manitoba, the total number of ad hoc appearances over a recent calendar year fluctuates between three and six. ${ }^{32}$ For a number of years, the Quebec Court of Appeal relied on the services of a single full-time ad hoc judge $^{33}$ from the provincial superior trial court, but opted for an increase in the number of full-time appeal judges rather than expanding the practice. In Canadian Provincial Courts of Appeal, the general rule is the near exclusive use of full-time appeal judges (supplemented as required by supernumerary judges when they are available). ${ }^{.4}$

24. As the anonymous reviewer pointed out: the low rate of success in defendant appeals is probably the result of Charter-related breathalyser appeals which skew the total because defence arguments are often very weak. The unusually high success rate of Crown appeals, however, remains significant. In British Columbia, the relcvant provincial legislation does not permit the use of provincial superior trial judges on an ad hoc basis. In Ontario, the legislation does permit it when needed, but in recent decades a scries of Chief Justices have been so reluctant to consider the practice that the permission amounts to a dead letter.

3. Usually a small court in which onc or more members must recuse themselves from consideration of a specific appeal: more rarely illness or non-judicial assignments or temporary surges in caseload.

32. See McCormick. "Cascload and Outpul of the Manitoba Court of Appeal 1991" Manimba Lau" Journal (forthcoming)

3. This apparent oxymoron is the term used in Qucbec and. perhaps, the least misleading way of labelling an unusual situation.

.4. Differences in the statutory regimes of the different Courts of Appeal drive part of this difference. In Alberta. all trial judges are formally ad hoc members ol the appeal court as well. although a fairly small subset of the irial bench is called upon to provide the bulk of such service. 
In Alberta, however, the use of members of the trial bench as ad hoc judges is a regular practice. ${ }^{35}$ (Alberta is also more willing than other provinces to follow the reverse logic of using appeal judges as ad hoc provincial superior trial judges, although this is much more rare. ${ }^{36}$ ) The advantages of the practice are two-fold: first. it provides a considerable degree of flexibility in the deployment of judicial resources to cope with fluctuations in the cascload of trial and appeal courts; and second, it allows, even forces, judges on both benches to be more aware of the perspectives and the imperatives of their respective roles. The disadvantage would be the increased difficulty of co-ordinating the activities of a functionally larger appeal bench with an even greater number of panels, and the possibility that the ad hoc judges would be somewhat more reluctant to be too critical of their own trial bench colleagues a concern that logically should apply as well to appeals from a trial decided by an appeal judge sitting ad hoc.

Forty-six different Queen's Bench judges, which is clearly more than half of those who served on the trial bench over the seven and a half year period, made appearances in conviction appeals as ad hoc judges of the Court of Appeal. Sixteen of these made less than half a dozen appearances each, so that the bulk of the ad hoc work is done by about 30 judges of the Court of Queen's Bench, three of whom (Mr. Justice Gallant, Madam Justice McFadyen and Mr. Justice Matheson) made more than fifty appearances, and three others (Mr. Justice Agrios, Mr. Justice Egbert and Mr. Justice Feehan) more than thirty. These six judges alone account for more than $40 \%$ of the ad hoc panel appearances for conviction appeals.

The number of ad hoc appearances is clearly large enough to provide the opportunity to assess their impact in that there is a sufficient run of cases to see if there is a difference in the voting behaviour of ad hoc judges as opposed to appeal judges, or if there is a systematic long-term difference in outcome depending on the composition of the panels. The relative infrequency of dissent ${ }^{37}$ (the product either of high caseload or of informal internal norms that discourage overt disagreement) makes the first approach unpromising, but Atkins and Green ${ }^{3 \mathrm{x}}$ have argued that over a sufficient run of cases, the pattern of outcomes may hint at the different voting tendencies obscured by a bias toward formal unanimity in decision-making. Dividing panels on the double criteria of the presence or absence of ad hoc judges, and the level of court from which the appeal derived, generates the patterns displayed in Table 6.

3. Even more so for sentence appeals, which will be dealt with in another paper.

4. In practice, for obvious reasons, this is usually limited to appeal court judges who were elevated from the trial bench. although formally all appeal cour judges are ad hor members of the trial bench as well.

37. The monthly caselists indicate dissents in only 66 of the $2000+$ pancl decisions, a dissent rate just over 3\%. Almost half of this is accounted for by a single judge Mr. Justice Harradence usually supporting an unsuccessful appeal against the Crown. Interestingly. the ad hoc judges account for roughly onc-lenth of the dissents. closely parallel to their one-tenth of all panel appearances. These rates seem low enough to suggest informal norms depressing the overt expression of disagreement. B.M. Atkins and J.J. Green. "Consensus on United States Courts of Appeals: Illusion or Reality?" (1976) 20 American Joumal of Political Sicience 735. 
The pattern is reasonably clear. It is not just that the presence of an ad hoc judge on the panel reduces the chance of a successful appeal (although this is a correct statement: an appeal is only five-sixths as likely to succeed if a Queen's Bench judge is sitting), but that the differential impact is entirely directed to appeals from the Queen's Bench itself. If three appeal court judges are sitting, an appeal from Provincial Court is slightly (5\%) more likely to succeed than an appeal from Queen's Bench. If the panel includes an ad hoc judge, the success rate for provincial court appeals is almost unchanged, but the likelihood of a successful Queen's bench appeal falls so far as to triple the spread to $15 \%$.

Table 6: Success Rate of Conviction Appeals

by Presence or Absence of Ad Hoc Judges, 1985-1992

\begin{tabular}{||l||l|l|l||}
\hline Appeal from & no ad hoc judges & $\begin{array}{l}\text { ad hoc judge } \\
\text { on panel }\end{array}$ & All Appeals \\
\hline \hline Provincial Court & $\begin{array}{l}41.1 \% \\
n=367\end{array}$ & $\begin{array}{l}42.4 \% \\
n=205\end{array}$ & $41.6 \%$ \\
\hline Queen's Bench & $\begin{array}{l}35.7 \% \\
n=995\end{array}$ & $\begin{array}{l}25.1 \% \\
n=438\end{array}$ & $32.5 \%$ \\
\hline All Appeals: & $37.2 \%$ & $30.7 \%$ & $35.1 \%$ \\
\hline
\end{tabular}

To some extent. thesc differences in outcome may well be the product of structural factors. The allocation of the lists between panels is probably less than random, such that panels with ad hoc judges receive sets of appeals that are skewed toward the more routine and less challenging in which the decisions will resolve the immediate case but have few wider implications: while the appeals whose jurisprudential impact is more likely to significant within and beyond the province are directed to full-time appeal judges only. This would seem a sensible and reasonable policy. The patterns may also be affected by the fact that only full-time appeal judges sit on the less frequent summer panels whose caseload is presumably comprised largely of unusual cases requiring expeditious handling. To this extent, the numbers in Table 6 must be taken with a grain of salt, although the differences still appear noteworthy.

\section{CASEFLOW IN THE ALBERTA COURT OF APPEAL}

As indicated above, there is a persisting indication that the long-term increase in appellate caseload has peaked in Alberta (and possibly in several other provinces as well); however, this slight downturn comes after a period of decades in which caseload rose steadily. The challenge that appeal courts have faced in recent years is to balance caseload and judicial capacity, so as to process appeals expeditiously while still giving each case the measured and careful consideration necessary for just resolution. Matching the readiness of appellants against the availability of appeal panels against the backdrop of rising caseload generates problems of caseflow, case management and, as the negative result, backlog cases that must wait for resolution until the resources are available to deal with them. 
All comparative indications are that Alberta has dealt reasonably well with the caseflow challenge. There is a significant backlog problem in Ontario and Quebec; measured against the other high-volume appeal courts [see Table I] Alberta does not by general report have a problem perhaps partly because the policy of the large-scale utilization of trial judges as ad hoc appeal judges expands judicial resources so as better to absorb a larger workload.

The data permit some discussion of the caseflow patterns in the Alberta Court of Appeal. Information was available on the date of trial decision for about $99 \%$ of the cases, and this permits comparison in terms of elapsed time between trial decision and appeal decision. In many ways this is not the most subtle or useful measure of court performance: to be totally fair, the appeal court rating clock should only start ticking when both parties to the appeal have filed the relevant documentation and are prepared to proceed, ${ }^{3 \prime \prime}$ but this information was simply not available for a large enough range of courses. Elapsed time from trial to appeal has the advantage of building from the "consumer" side of the process, but it is used here with full acknowledgment of the fact that the Court of Appeal is by no means responsible for all, and possibly not even for most, of the passage of time.

The discussion of caseflow that follows is based entirely on the length of time elapsing from trial judgment to appeal panel hearing. This is usually, but not always, the day that the appeal decision is delivered in 1989, the only year for which I have complete lists, only one decision in six was reserved, but where these two dates differ the reference is to the appellate hearing. A very small number of conviction appeals involve a second day of court time, but the number is so small that there is no significant distortion in simply counting time to the first day of court hearing. Figures are provided for both the average case and the median case (that is: that case so situated that the number of cases handled more quickly and the number handled less quickly are identical).

Table 7: Average and Median Times from Trial to Appeal Conviction Appeals in the Alberta Court of Appeal, 1985-92

\begin{tabular}{||l|l|l||}
\hline Year & Average & Median \\
\hline \hline $1984-85^{\text {t1 }}$ & 276.4 days & 202 days \\
\hline $1985-86$ & 249.7 days & 215 days \\
\hline $1986-87$ & 260.5 days & 219 days \\
\hline $1987-88$ & 289.2 days & 233 days \\
\hline $1988-89$ & 279.7 days & 262 days \\
\hline
\end{tabular}

From other stources, it seems clear that two significant components of the time lag are the production of appeal hooks and the prexessing of applications for Iegal aid.

Information available only for the latter half of 1984-85. 


\begin{tabular}{||l||l|l|}
\hline Year & Average & Median \\
\hline $1989-90$ & 308.8 days & 271 days \\
\hline $1990-91$ & 296.0 days & 268 days \\
\hline $1991-92$ & 316.9 days & 275 days \\
\hline
\end{tabular}

Between 1985 and 1992, the average appeal was heard (and usually decided) about nine and a half months (282 days) after the trial decisions were handed down. The median figure is slightly lower, at eight months (245 days), which compares with Ontario's median figure of 328 days for conviction appeals over a comparable time period." There has been a gradual and general upward movement over the years; both the average and the median figures for 1991-2 are almost 30\% higher than those for 1985-86, the first full year for which data is available. The percentage of cases cleared within three months of trial is similarly down from $10.8 \%$ in $1984-5$ to $4.7 \%$ in 1990-1 and 1991-2; and the percentage of cases cleared within six months of trial is similarly down from $40 \%$ in 1985-6 to below 15\% of 1991-2. The percentage of cases taking one year or more has risen more modestly, from $20 \%$ in $1984-85$ and $1985-86$ to $25 \%$ in $1991-92$. It is at first glance curious that rising average time correlates with decreasing caseflow, but the relationship might well be logical even tautological rather than causal in that the only way the Court could handle its larger number of cases in the mid-and late 1980s was by rushing them through more quickly. It does not necessarily follow that the numbers for the mid-80s constitute a "normal" time or a fair basis for evaluation; it might just as plausibly represent the haste that makes waste. A further factor might be the routinization of Charter arguments in appeals as the novelty of the Charter fades, more and more lawyers include Charter arguments in their appeals, thereby expanding the grounds on which they are presenting argument and the issues that the appeal court might resolve but this hypothesis cannot be tested directly because the registrar's records do not identify cases involving the Charter.

Table 8: Average and Median Times from Trial to Appeal by Type of Offense; Conviction Appeals 1985-1992

\begin{tabular}{||l||l|l||}
\hline Type of Offense & Average & Median \\
\hline \hline drug related offenses & 363 days & 285 days \\
\hline crimes against the person & 307 days & 265 days \\
\hline wrongful acts & 285 days & 278 days \\
\hline miscellaneous appeals & 267 days & 210 days \\
\hline crimes against property & 257 days & 237 days \\
\hline
\end{tabular}




\begin{tabular}{||l||l|l||}
\hline \hline Type of Offense & Average & Median \\
\hline motor vehicle offenses & 243 days & 213 days \\
\hline ALL OFFENSES: & 283 days & 245 days \\
\hline
\end{tabular}

There seems to be more substance to comparisons derived from the different clearing rates for the various types of offences, as shown in Table 8 . Motor vehicle cases are cleared most quickly, drug-related offenses the least quickly, and the difference between the two amounts to several months for both average and median figures. $37 \%$ of all motor vehicle appeals. and $36 \%$ of property appeals, were cleared within six months or less of the trial decision. Only $14 \%$ of drug appeals were resolved this quickly. The unusually large spread between the average and median times for drug-related offenses suggests a small number of cases that took an unusually long time to resolve, but the fact that the median is still several weeks higher than for any other type of offense indicates that this is not the only factor.

An explanation might be sought in bail practices, and in the logical dynamics of an appellant who is granted interim release and might presumably be in less hurry to resolve the issue. Clearly. bail is more frequent in appeals involving drug-related offenses than for other types of offenses; one drug-related appeal in three, but only one appellant in five for crimes against the person or against property, and only one appellant in twelve for motor vehicle cases, is freed on bail. However, appeals involving appellants who are granted bail do not drag on longer than appeals involving parties who remain in custody. The average for all appeals is $\mathbf{2 8 3}$ days, the average for appeals where bail is involved only 299 days. Nor do success rates differ significantly: $35.1 \%$ for all appeals, and $37.3 \%$ for appellants granted interim release. The impact of the granting of bail is surprisingly neutral, and an explanation for the dragging pace of drug-related appeals must be sought elsewhere.

Table 9: Clearing Rates and Reversal Rates, by Percentile

Crown and Defendant Appcals; Conviction Appeals 1985-1992

\begin{tabular}{||c||c|c|l|l||}
\hline Percentile & $\begin{array}{c}\text { Crown } \\
\text { Days }\end{array}$ & $\begin{array}{c}\text { Crown } \\
\text { Success Rate }\end{array}$ & $\begin{array}{l}\text { Defendant } \\
\text { Days }\end{array}$ & $\begin{array}{l}\text { Defendant } \\
\text { Success Rate }\end{array}$ \\
\hline \hline $10 \%$ & 101 & $45.5 \%$ & 102 & $31.0 \%$ \\
\hline $25 \%$ & 161 & $49.0 \%$ & 170 & $32.4 \%$ \\
\hline $50 \%$ & 232 & $63.0 \%$ & 249 & $32.1 \%$ \\
\hline $75 \%$ & 245 & $56.8 \%$ & 354 & $31.4 \%$ \\
\hline $90 \%$ & 294 & $55.1 \%$ & 481 & $30.4 \%$ \\
\hline $100 \%$ & 1861 & $50.0 \%$ & 1532 & $28.7 \%$ \\
\hline
\end{tabular}


Note: Clearing time counted in days from trial decision to appeal decision.

There is also no real difference in clearance rate between Crown appeals and defendant appeals; the average for the former is 283.8 days, for the latter 282.5 days. This is surprising, because it contrasts so strikingly with Ontario's experience. ${ }^{42}$ In that province, there is a considerable difference between Crown and defendant appeals, with the former moving rapidly and the latter dragging. In Ontario, there is a 105 day gap between Crown and defendant appeals at the 50th percentile. In Alberta, the gap is only 17 days. (In both provinces there is a similar pattern of a dramatically ballooning of the gap for the last deciles of slow-paced appeals.) At least at first glance, it would appear that the Alberta Court's practices of trying to "force the pace" and manage the conviction appeal lists is generally successful, and the parallel pacing of Crown and defendant appeals is the outcome. It is curious that in Alberta, unlike Ontario, this results in a much higher success rate for Crown appeals.

\section{CONCLUSION}

The purpose of this paper has been to provide a statistical summary of conviction appeals in the Alberta Court of Appeal between January 11985 and June 30 1992. The diversity of Table $I$, and the varying dynamics of the appeal process they suggest, cast some doubt on the extent to which these findings can be generalized. Some of the general patterns of Alberta Court of Appeal processes such as a gradual increase in the average and median clearing times for conviction appeals, and a "one-in-three" success rate, and a strong preponderance of defendant over Crown appeals, and a significant number of appeals direct from Provincial Court might well be true of all or most of the provinces. Others, such as the much higher success rate for Crown appeals, ${ }^{43}$ and the varying ratios of defendant and Crown appeals and the patterns suggested by the success rates for different types of offence, might be more reflective of unique temporal and locational factors. The curious fact that Alberta, the fourth largest province, may well lead the country for the absolute number of conviction appeals makes the focus of this research paper at one and the same time more intriguingly important and less easily generalizable.

The sui generis nature of the data-base on which this paper was based requires the tone of exposition rather than of criticism or comparison: these simply are the patterns that the thousands of individual appeals, each the product of judicial deliberations and reasoned arguments, adds up to. The point is not to suggest that these patterns should be different in some specific way. but simply that information about what the patterns are is both interesting and of use in understanding the broader context created by those individual decisions over time.

43. There does not scem to be a difference in the success rates for Crown and defendant appeals in Ontario; sec ihid. 